Supporting information

\title{
Puromycin-modified silica microspheres based nascent proteomics (PMSNP) method for rapid and deep nascent proteome profile
}

Yuanyu Huang, ${ }^{1}$ Quanqing Zhang, ${ }^{2}$ Lujie Yang, ${ }^{1}$ Ling Lin, ${ }^{1}$ Juanjuan Xie, ${ }^{1}$ Jun Yao, ${ }^{1}$ Xinwen Zhou, ${ }^{1}$ Lei Zhang, ${ }^{1}$ Huali Shen, ${ }^{*}, 1,3,4$ Pengyuan Yang, ${ }^{*}, 1,3,4$

${ }^{1}$ Department of Chemistry and Institutes of Biomedical Sciences, Fudan University, Shanghai, 200433, P.R.

China

${ }^{2}$ Department of Chemistry, University of California, Riverside, CA, 92521, USA

${ }^{3}$ Department of Systems Biology for Medicine and School of Basic Medical Sciences, Fudan University, Shanghai, 200032, P.R. China

${ }^{4}$ NHC Key Laboratory of Glycoconjugates Research, Fudan University, Shanghai, 200032, P.R. China

${ }^{*}$ Huali Shen and Pengyuan Yang

Email: shenhuali@fudan.edu.cn

pyyang@fudan.edu.cn 
Table of Contents:

\section{Experiment section}

Reagents

Synthesis of silica microspheres

Synthesis of silica azide

Cell culture and lipopolysaccharide (LPS) treatment

MALDI-MS and LC-MS/MS analysis

Label-free quantification in mass spectrometry

Data analysis

Filtering of MS Data

Data availability

\section{Supporting figures}

Supplemental Fig. S1 (A) Nitrogen adsorption isotherms and (B) pore size distribution of the fabricated silica microspheres measured at $77 \mathrm{~K}$.

Supplemental Fig. S2 FT-IR spectra of azide modified silica synthesized from silica microspheres reacting with 3-Azidopropyltrimethoxysilane, and 3-chloropropyltrimethoxysilica reacting with sodium azide.

Supplemental Fig. S3 SEM images of (A) silica azide and (B) PMS.

Supplemental Fig. S4 The dispersion photographs of the PMS in various solvents at $25^{\circ} \mathrm{C}$ after ultrasonic the dispersion for 1 minute with (A) $0 \mu \mathrm{g} / \mu \mathrm{L}$ in water, (B) $1 \mu \mathrm{g} / \mu \mathrm{L}$ in acetonitrile, (C) $1 \mu \mathrm{g} / \mu \mathrm{L}$ in ethanol, (D) 1 $\mu \mathrm{g} / \mu \mathrm{L}$ in water, (E) $1 \mu \mathrm{g} / \mu \mathrm{L}$ in urea/SDS buffer and (F) $10 \mu \mathrm{g} / \mu \mathrm{L}$ in water.

Supplemental Fig. S5 FT-IR spectra of silica azide (black curve) and PMS (red curve) at the region of stretching vibration absorption of unsaturated carbon-carbon bond $\left(1800-1400 \mathrm{~cm}^{-1}\right)$.

Supplemental Fig. S6 FT-IR spectra of (A) silica azide, (B) PMS in three synthetic replicates. Infrared absorption from (C) silica azide and (D) PMS at the region of stretching vibration absorption of unsaturated carbon-carbon bond (1800-1400 $\left.\mathrm{cm}^{-1}\right)$. Black, blue and green curve represents three synthetic replicates of silica azide. Red, orange and olive curve represents three synthetic replicates of PMS.

Supplemental Fig. S7 Solid state ${ }^{1} \mathrm{H}$ cross-polarization magic-angle spinning (CP/MAS) NMR of sodium aizde and PMS.

Supplemental Fig. S8 TEM image of (A) reacted PMS with RNCs and (B) reacted PMS after a series of washing procedures and on beads digestion.

Supplemental Fig. S9 Descending acetonitrile gradient washing procedures to avoid non-specific binding. The MS intensities of two characteristic nascent peptides MVYISNGQVLDSR of SELK_HUMAN (blue bars) and MTELETAMGMIIDVFSR of S100P_HUMAN (orange bars) and two representative non-specific binding peptides DSHGVAQVRFVTGNK of RS13_HUMAN (yellow bars) and ISLGLPVGAVINCADNTGAK of RL23_HUMAN (gray bars) were monitored at each washing off step: non washing (Step 0); washing the reacted PMS with 80\% ACN (Step 1); 60\% ACN (Step 2); 50\% ACN (Step 3). The intensities changes of these peptides were listed in the inset table. 
Supplemental Fig. S10 Optimization of the (A) usage amount of PMS, (B) capture time and (C) on beads digestion time for the enrichment of nascent proteins in HeLa RNCs.

Supplemental Fig. S11 Enrichment reproducibility of PMS evaluated by the triplicate capture of nascent peptides MVYISNGQVLDSR ( $\mathrm{m} / \mathrm{z}=1481.8)$ and MTELETAMGMIIDVFSR $(\mathrm{m} / \mathrm{z}=1943.9)$.

Supplemental Fig. S12 Venn diagram of overlapping identified proteins in HeLa RNCs and nascent proteins detected by PMSNP of the technical triplicates.

Supplemental Fig. S13 Protein abundance distribution in identified (A) RNCs proteins and (B) nascent proteins in HeLa cells sorted by the protein score.

Supplemental Fig. S14 Confidence interval of replicate in each MS identification of (A) HeLa cells RNCs, (B) PMSNP in HeLa cells, (C) Mouse brains proteomes, (D) PMSNP in mouse brains, PMSNP in (E) 0, (F) 10, (G) 30, (H) 60 minute's LPS stimulated HeLa cells, Cellular proteomes in (I) 0, (J) 10, (K) 30, (L) 60 minute's LPS stimulated HeLa cells. The blue dotted lines and blue paint zones marked the limit of confidence interval with the significance level of 0.05 . The red dotted lines and red paint zones indicated the FC $>2$ or $<-2$ as the criteria of filtering significantly differential expressed proteins.

Supplemental Fig. S15 KEGG pathway analysis of identified proteins increased in the expression from HeLa RNCs.

Supplemental Fig. S16 GO terms interaction network of identified nascent proteins in HeLa cells.

Supplemental Fig. S17 Venn diagram of overlapping identified proteins in the full mouse brains and nascent proteins from mouse brains detected by PMSNP of the technical triplicates.

Supplemental Fig. S18 Fold change of 3937 of nascent proteins abundance against full proteins in mouse brains.

Supplemental Fig. S19 Venn diagram of overlapping identified nascent and cellular proteins in the LPS stimulated HeLa cells of four stimulation time groups in technical triplicates.

Supplemental Fig. S20 Color-coded Pearson correlation coefficient for the comparison of technical triplicates of identified (A) nascent proteins and (B) cellular proteins in each LPS stimulation time.

\section{Supporting tables}

Supplemental Table S1. Comparison of different methods in identification of nascent proteomes.

Supplemental Table S2. Numbers of proteins identified by PMSNP and cellular proteomics in each LPS stimulation time in HeLa cells.

Supplemental Table S3. Label-free quantified up and down regulated protein amount $(\mathrm{FC}>2$ or $\mathrm{FC}<-2$, and $\mathrm{P}$ $<0.05$ ) identified by PMSNP and cellular proteomics in each stimulation time against 0 minute's stimulation. Percentage of the up or down regulated proteins were showed in the brackets.

\section{Reference}




\section{Experimental Section}

\section{Reagents}

Ammonia solution $\left(\mathrm{NH}_{3} \cdot \mathrm{H}_{2} \mathrm{O}, \mathrm{AR}, 25-28 \%\right)$, ethanol $\left(\mathrm{C}_{2} \mathrm{H}_{5} \mathrm{OH}, \mathrm{AR}\right)$, methanol $\left(\mathrm{CH}_{3} \mathrm{OH}, \mathrm{AR}\right)$, tetraethyl orthosilicate (TEOS, 99.99\%), tetrabutylammonium iodide (TBAI, 99\%), sodium sulfate anhydrous $\left(\mathrm{Na}_{2} \mathrm{SO}_{4}, \mathrm{AR}\right)$, (3-Chloropropyl)trimethoxysilan (98\%), N,N-Dimethylformamide (DMF, AR) were purchased from aladdin (Shanghai, China). Sodium azide $\left(\mathrm{NaN}_{3}\right.$, ReagentPlus ${ }^{\oplus}$ ) was purchased from Merck (Darmstadt, Germany). 2Butanone (AR), toluene (AR) and dichloromethane $\left(\mathrm{CH}_{2} \mathrm{Cl}_{2}, \mathrm{AR}\right)$ were purchased from Sinopharm Chemical Reagent (Shanghai, China).

\section{Synthesis of silica microspheres}

Silica microspheres were fabricated via Stöber method. ${ }^{1}$ Some alterations were applied to the method. To a 250 $\mathrm{mL}$ round bottom flask were added $125 \mathrm{~mL}$ of ethanol, $2.5 \mathrm{~mL}$ of Milli-Q water, and $8.4 \mathrm{~mL}$ of ammonia solution (25\%). After stirring at $40^{\circ} \mathrm{C}$ for $2 \mathrm{~h}, 7.5 \mathrm{~mL}$ of TEOS was added to the mixture drop by drop. The reaction was continued by stirring at $40^{\circ} \mathrm{C}$ for overnight. The synthesized silica microspheres in white sediments were collected by centrifugation at $8000 \mathrm{~g}$ for 10 minutes and washed by $3 \mathrm{ml}$ of ethanol and $3 \mathrm{ml}$ of Milli-Q water for five times each. The silica microspheres were dried at $110{ }^{\circ} \mathrm{C}$ under vacuum and ground into white powders for the surface modification of azide groups.

\section{Synthesis of silica azide}

Azido modification was carried out by 3-azidopropyltriethoxysilane which was synthesized according to a previous method with some alterations. ${ }^{2} 462 \mu \mathrm{L}$ of 3-chloropropyltrimethoxysilane $(500 \mathrm{mg}, 2.1 \mathrm{mmol})$ and tetrabutylamonium iodide (TBAI, $20 \mathrm{mg}, 0.05 \mathrm{mmol}$ ) were added to $25 \mathrm{ml}$ of butanone in a $100 \mathrm{ml}$ round bottom flask. Then $624 \mathrm{mg}$ of sodium azide $\left(\mathrm{NaN}_{3}, 9.6 \mathrm{mmol}\right)$ was mixed in the reaction mixture and heated under reflux at approximately $80^{\circ} \mathrm{C}$ for 50 hours. The reaction was terminated by $8000 \mathrm{~g}$ centrifugation for the remove of TBAI and $\mathrm{NaCl}$. The supernant was collected in $100 \mathrm{ml}$ flask and the solvent was evaporated under vacuum. The yellow liquid residue was dissolved in $75 \mathrm{ml}$ of dichloromethane $\left(\mathrm{CH}_{2} \mathrm{Cl}_{2}\right)$ and washed with $10 \mathrm{ml}$ of Milli-Q water twice. The organic phase was dried with sodium sulfate anhydrous $\left(\mathrm{Na}_{2} \mathrm{SO}_{4}\right)$ and evaporated under vacuum to give the azido reagent 3-azidopropyltriethoxysilane. The syrup was dissolved in $20 \mathrm{ml}$ of toluene and $800 \mathrm{mg}$ of synthesized silica microspheres were dispersed into the solution. The reaction mixture was heated at $110{ }^{\circ} \mathrm{C}$ for 2 hours under reflux. Then the mixture was transferred to a $100 \mathrm{ml}$ flask and the solvent was evaporated to half of the volume under vacuum. Another $10 \mathrm{ml}$ of toluene was added and heated under reflux for 1 hour. The reaction was terminated by $8000 \mathrm{~g}$ centrifugation for the remove of supernant and washed with $50 \mathrm{ml}$ of $\mathrm{CH}_{2} \mathrm{Cl}_{2}$ for four times. The fabricated silica azide were dried under vacuum at $50^{\circ} \mathrm{C}$ for 16 hours and prepared for the click reaction immediately.

\section{Cell culture and lipopolysaccharide (LPS) treatment}

HeLa cells were grown in Dulbecco's modified Eagle's medium (DMEM) supplemented with 10\% (vol/vol) fetal bovine serum (FBS, Gibco), $100 \mu \mathrm{g} / \mathrm{mL}$ streptomycin and $100 \mathrm{U} / \mathrm{mL}$ penicillin. Cells were grown at $37^{\circ} \mathrm{C}$ in a $5 \% \mathrm{CO}_{2}$ incubator. In the biological stress model, LPS (Sigma-Aldrich) was added to the flasks of HeLa cells with the 
concentration of $1 \mu \mathrm{g} / \mathrm{mL}$ when the cells were grown up to $80 \%$ confluence approximately. After the stimulation of 0 , 10,30 and 60 minutes, the cells were collected as pellets by centrifugation at $1,000 \mathrm{~g}$ for 4 min at $4{ }^{\circ} \mathrm{C}$ for further use.

\section{MALDI-MS and LC-MS/MS analysis}

Peptides used for the method optimization were analyzed by MALDI-MS on the 5800 Proteomics Analyzer (Applied Biosystems, Framingham, MA, USA) with the Nd-YAG laser at $355 \mathrm{~nm}$, a repetition rate of $400 \mathrm{~Hz}$ and an acceleration voltage of $20 \mathrm{kV}$. Peptides used for the identification of nascent proteomics were loaded on the trap column (Thermo Scientific Acclaim PepMap C18, $100 \mu \mathrm{m} \times 2 \mathrm{~cm}$ ) in $3 \mathrm{~min}$ at a flow rate of $10 \mu \mathrm{L} / \mathrm{min}$. The sample was subsequently separated with an analytical column (Thermo Scientific Acclaim PepMap C18, $75 \mu \mathrm{m} \times 25 \mathrm{~cm}$ ). For gradient separation in nascent proteomics, $\mathrm{H}_{2} \mathrm{O}$ /FA (99.9: 0.1) was used as the mobile phase A, and ACN/FA (99.9:0.1) was the mobile phase B. The gradient elution was per-formed as follows: $6 \% \mathrm{~B}$ was held for $5 \mathrm{~min}$. Then, from $6 \%$ to $35 \%$, B was held for $100 \mathrm{~min}$, and from $35 \%$ to $50 \%$, B was held for $9 \mathrm{~min}$. Then, from $50 \%$ to $100 \%$ for $1 \mathrm{~min}$. Finally, at $100 \%$, B was held for $5 \mathrm{~min}$. The column flow rate was maintained at $300 \mathrm{~nL} / \mathrm{min}$ and column temperature was maintained at $40^{\circ} \mathrm{C}$. The electrospray voltage of $2.0 \mathrm{kV}$ versus the inlet of the mass spectrometer was used. The EASY-nLC system (Thermo Scientific) was coupled to Orbitrap Exploris 480 (Thermo Scientific) Survey full-scan MS spectra (m/z 350-1600) were acquired by the Orbitrap with a mass resolution of $120000 \mathrm{at} \mathrm{m} / \mathrm{z}$. The AGC target was set to 300. Precursor ions with charge states from $2+$ to $6+$ were selected with an isolation window of $1.6 \mathrm{~m} / \mathrm{z}$ and fragmented by high energy collision dissociation (HCD) with a dynamic exclusion duration of $40 \mathrm{~s}$. For gradient separation in LPS-stimulated nascent proteomics, $\mathrm{H}_{2} \mathrm{O} / \mathrm{FA}$ (99.9:0.1) was used as the mobile phase A, and ACN/FA (99.9:0.1) was the mobile phase B. The gradient elution was performed as follows: $2 \%$ B was held for 5 min. Then, from $2 \%$ to $22 \%$, B was held for $40 \mathrm{~min}$, and from $22 \%$ to $37 \%$, B was held for $5 \mathrm{~min}$. Then, from $37 \%$ to $80 \%$ for $5 \mathrm{~min}$. Finally, at $80 \%$, B was held for $5 \mathrm{~min}$. The column flow rate was maintained at $300 \mathrm{~nL} / \mathrm{min}$ and column temperature was maintained at $50^{\circ} \mathrm{C}$. The electrospray voltage of $1.5 \mathrm{kV}$ versus the inlet of the mass spectrometer was used. The UHPLC system (Bruker) was coupled to timsTOF Pro (Bruker). Survey full-scan MS spectra (m/z 100-1700) were acquired by the timsTOF. Precursor ions with charge states from $1+$ to $5+$ were selected with an isolation width of $2.0 \mathrm{~m} / \mathrm{z}$ when the mass lower than $700 \mathrm{~m} / \mathrm{z}, 3.0 \mathrm{~m} / \mathrm{z}$ when the mass higher than $800 \mathrm{~m} / \mathrm{z}$ and a linear width was set from 700 to $800 \mathrm{~m} / \mathrm{z}$. Precursor ions were fragmented by collision induced dissociation (CID) with an active exclusion released after 24 s. PEAKS Online X build 1.3 (Bioinformatics Solutions Inc.) with the MASCOT v2.3.2 search engine was used for all searches of the data-base. The database was the Swiss-Prot database (Release 2020-08-03, human with 20375 sequences and mouse with 17046 sequences). The mass tolerance of the precursor ion was set to $10 \mathrm{ppm}$ and that of the fragment ions was set to $50 \mathrm{mmu}$. The peptide false discovery rate (FDR) was set to $1 \%$. Trypsin was chosen as the proteolytic enzyme and up to two miss cleavages were allowed. Carbamidomethyl on cysteine was set as a fixed modification. Oxidation on methionine and deamidation on asparagine were set as variable modifications.

\section{Data analysis}

Gene ontology (GO) enrichments analysis have been performed through the PANTHER overrepresentation test (Released 20200728). Fisher's Exact was set as the test type and calculated false discovery rate was the correlation method. Enrichment networks of nascent proteins identified in mouse brains with different distributed functions were performed using Metascape (http://metascape.org). Nascent proteins up-regulated in different LPS-stimulated response were analyzed by using Ingenuity Pathway Analysis (IPA, Ingenuity Systems, Redwood City, CA). A score of at least 10 focus proteins were considered to be biologically relevant to the networks. 


\section{Label-free quantification in mass spectrometry}

Relative label-free quantification (LFQ) of the LC-MS/MS results was carried out by the search engine MaxQuant software V1.6.10.43. All raw files were analyzed in a single run with default parameters. ${ }^{3,4}$ Database searches were performed using the Swiss-Prot database, which Homo sapiens (Human) for the results of HeLa cells and Mus musculus (Mouse) for the results of mouse brains. The absolute protein abundances were represented by the protein expression values, which were iBAQ values. ${ }^{5}$ The total protein intensity were the sum of the corresponding peptides intensity and then converted to $\log 2$ values for the final fold change calculations. The quantitative profiles were filtered for the missing peptide intensity values. Gaussian distribution with a median shifted from the measured data distribution median towards low expression was set as the imputation values. The mode parameter defined the measured data distribution to be used in the calculation of the random distribution. Missing values were imputed using the distribution width of 0.2 and down-shift of $1.8 .{ }^{5}$ Log ratios were calculated as the difference in average $\log 2$ LFQ intensity values between the tested conditions (two-tailed, Student's t test, FDR lower than 0.01). Calculations were run in the RStudio 1.2.1335 (RStudio, Inc.).

\section{Filtering of MS Data}

The abundance of nascent protein was calculated by the fold change $(\mathrm{FC})=\log 2$ (Nascent proteins $v s \mathrm{RNC}$ proteins or whole tissue proteins) in each replicate, followed by averaging across replicates. Candidates were pursued with FC $>2$ for all datasets, $\mathrm{P}$ values were calculated for the FC ratios using a two-tailed, one-sample $t$ test against the assumed mean of 0 , with $\mathrm{P}$ value of $<0.05$ as the significance cutoff. ${ }^{6}$ Filtering of significantly differential expressed nascent proteins or RNCs proteins by the FC ratios was calculated by the proteins outside the confidence interval. In each replicate FC > 2 ensured these proteins inside the significance level of 0.05 were shown in Figure S13.

\section{Data availability}

The raw and search files are available on a publicly accessible web-site: https://www.iprox.org. The project name is "Nascent Proteomes Identified by PMSNP" and subproject ID is IPX000264500. Search result datasets were all provided in Supplementary Datasets (XLSX), including table of identified proteins from HeLa cells by RNCs proteomics and PMSNP with protein intensities (Dataset S1), table of identified proteins from mouse brains by whole tissue proteomes and PMSNP with protein intensities (Dataset S2), table of identified proteins from LPS stimulated HeLa cells with protein intensities by PMSNP (Dataset S3) and cellular proteomics (Dataset S4). 
A

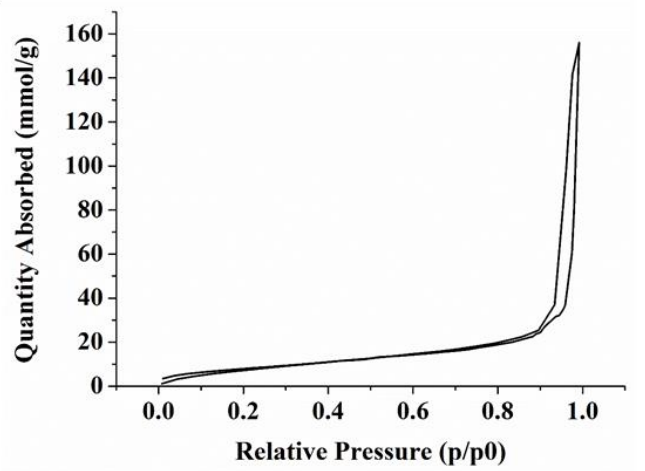

B

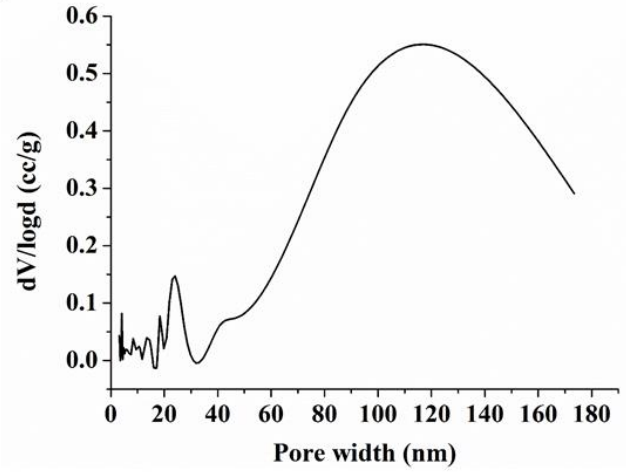

Figure S1. (A) Nitrogen adsorption isotherms and (B) pore size distribution of the fabricated silica microspheres measured at $77 \mathrm{~K}$. 

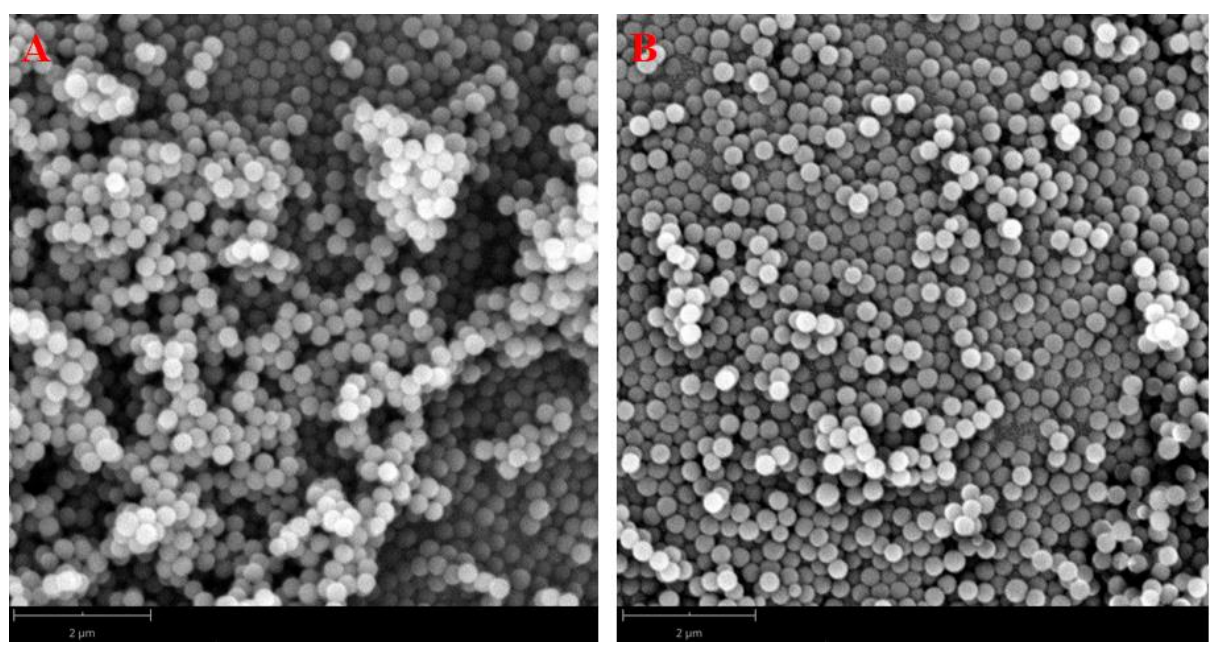

Figure S2. SEM images of (A) silica azide and (B) PMS. 


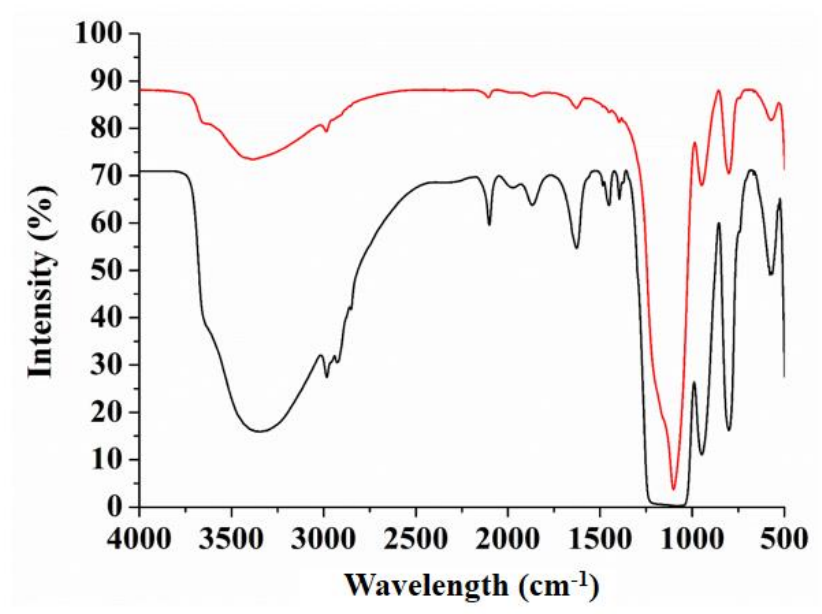

Figure S3. FT-IR spectra of azide modified silica synthesized from silica microspheres reacting with 3Azidopropyltrimethoxysilane (black curve), ${ }^{7}$ and 3-chloropropyltrimethoxysilica reacting with sodium azide (red curve). ${ }^{2}$ 


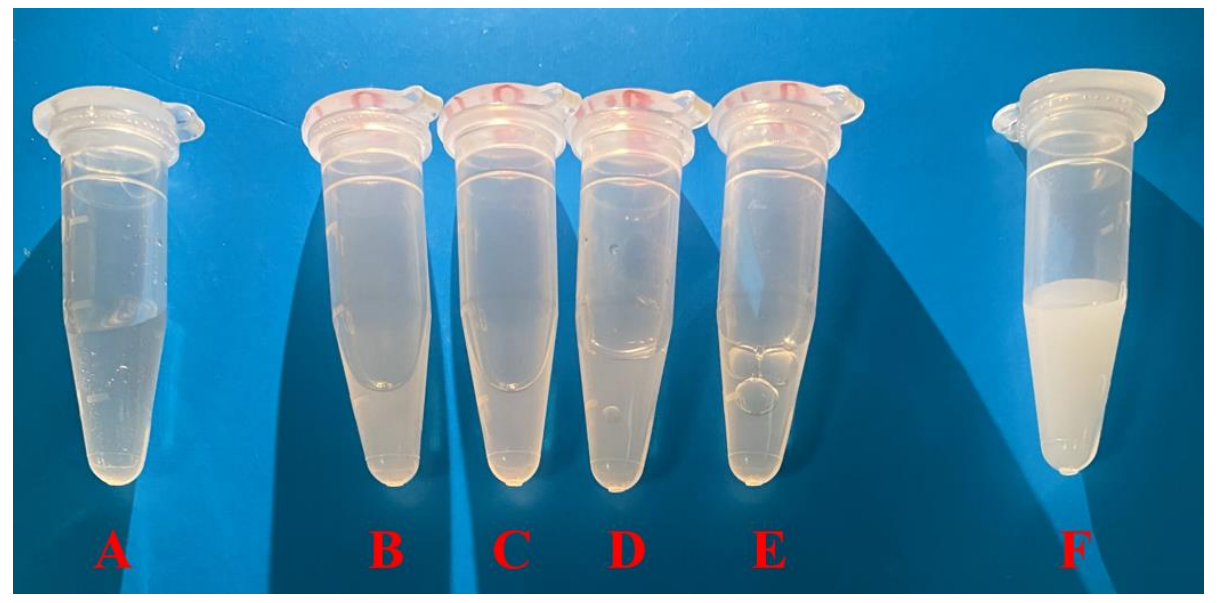

Figure S4. The dispersion photographs of the PMS in various solvents at $25 \mathrm{oC}$ after ultrasonic the dispersion for 1 minute with (A) $0 \mu \mathrm{g} / \mu \mathrm{L}$ in water, (B) $1 \mu \mathrm{g} / \mu \mathrm{L}$ in acetonitrile, (C) $1 \mu \mathrm{g} / \mu \mathrm{L}$ in ethanol, (D) $1 \mu \mathrm{g} / \mu \mathrm{L}$ in water, (E) 1 $\mu \mathrm{g} / \mu \mathrm{L}$ in urea/SDS buffer (50 mM Tris-HCl, $\mathrm{pH}=7.5,8 \mathrm{M}$ urea, $2 \% \mathrm{SDS}$ and $200 \mathrm{mM} \mathrm{NaCl}$ in RNase-free water) and (F) $10 \mu \mathrm{g} / \mu \mathrm{L}$ in water. 


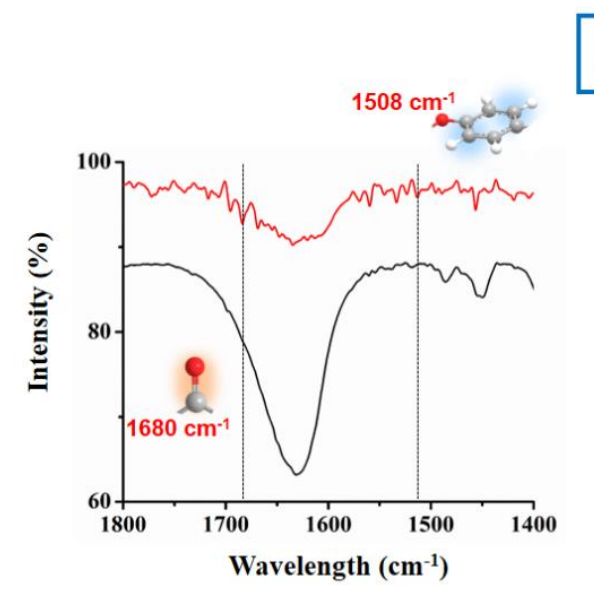

Figure S5. FT-IR spectra of silica azide (black curve) and PMS (red curve) at the region of stretching vibration absorption of unsaturated carbon-carbon bond $\left(1800-1400 \mathrm{~cm}^{-1}\right)$. 
A

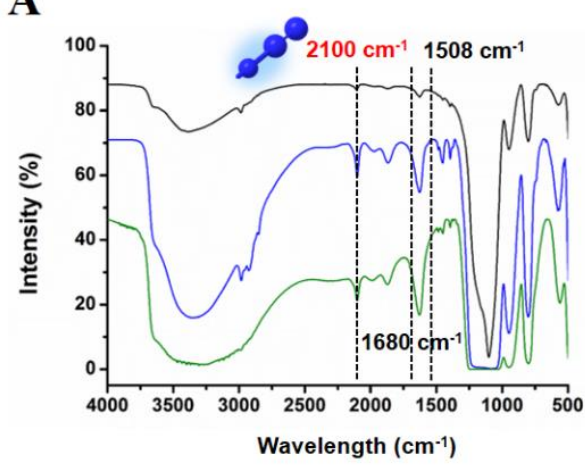

B

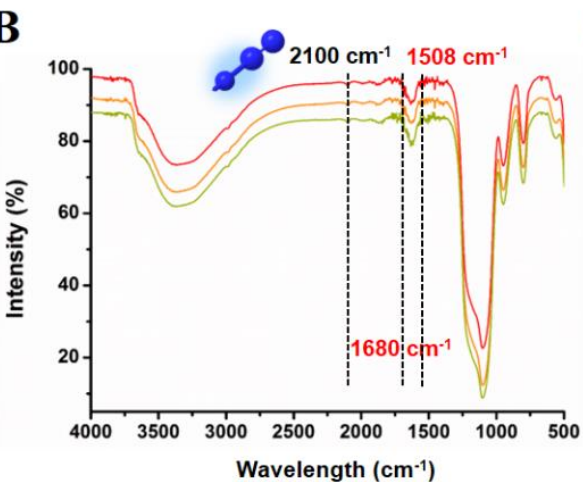

C

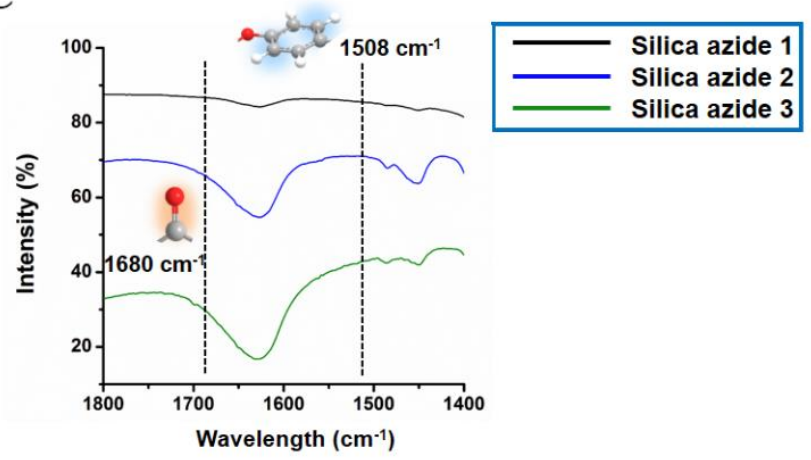

D

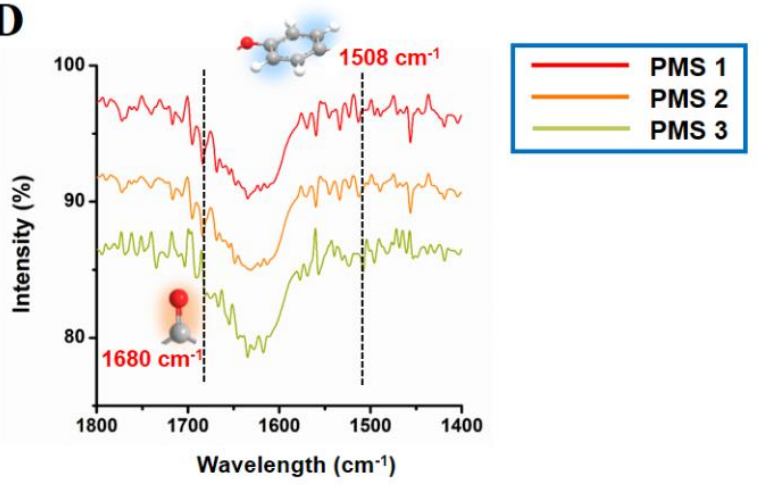

Figure S6. FT-IR spectra of (A) silica azide, (B) PMS in three synthetic replicates. Infrared absorption from (C) silica azide and (D) PMS at the region of stretching vibration absorption of unsaturated carbon-carbon bond (1800-1400 $\mathrm{cm}^{-1}$ ). Black, blue and green curve represents three synthetic replicates of silica azide. Red, orange and olive curve represents three synthetic replicates of PMS. 


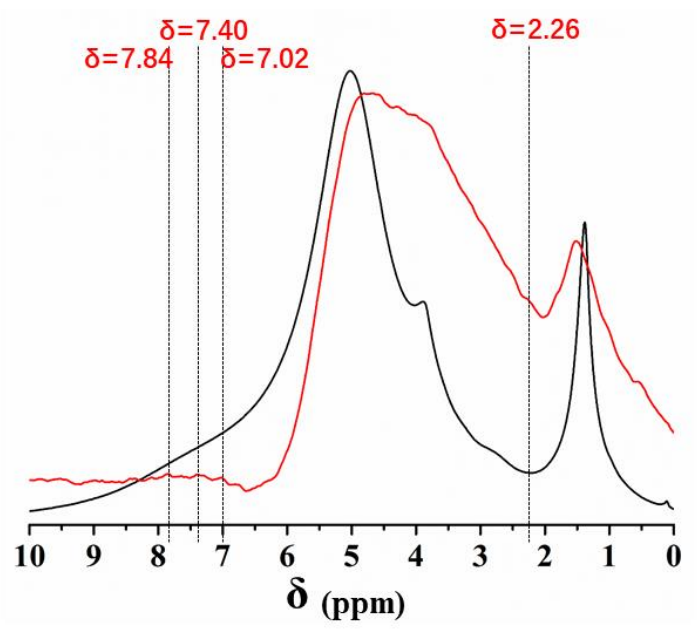

Figure S7. Solid state ${ }^{1} \mathrm{H}$ cross-polarization magic-angle spinning (CP/MAS) NMR of sodium aizde (black curve), and PMS (red curve). 


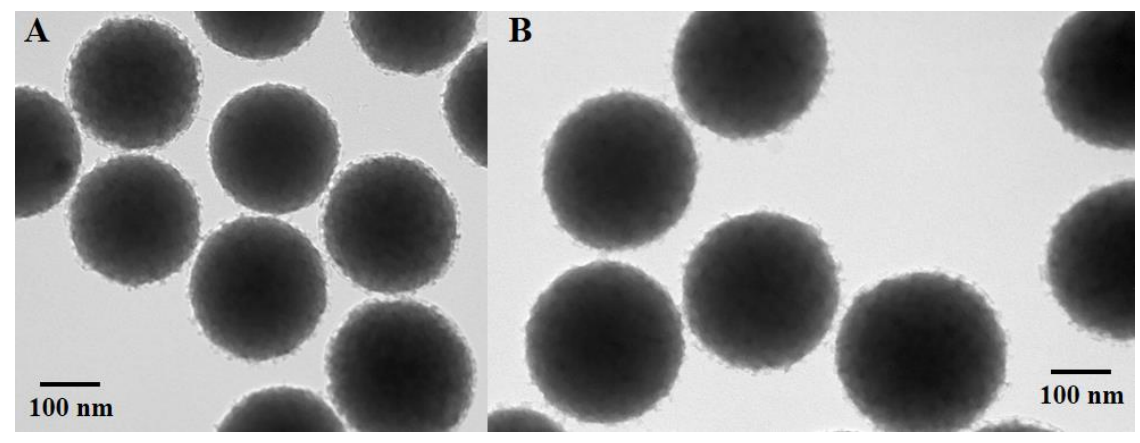

Figure S8. TEM image of (A) reacted PMS with RNCs and (B) reacted PMS after a series of washing procedures and on beads digestion. 


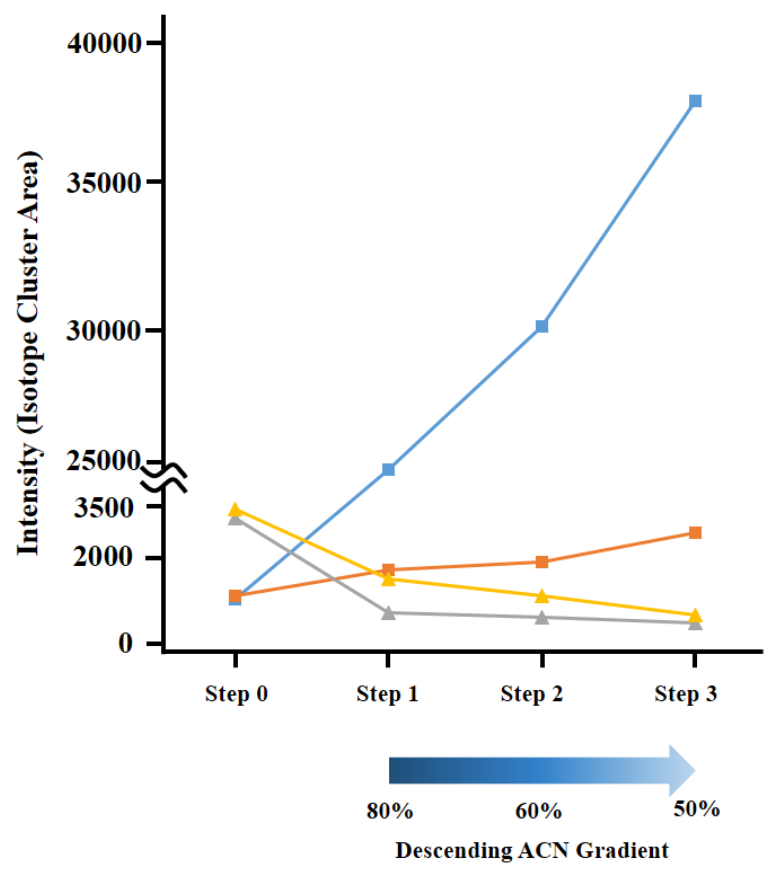

\begin{tabular}{|c|c|c|c|c|}
\hline$\rightarrow$ & \multicolumn{4}{|c|}{$\begin{array}{l}\text { 1481.8: } \text { MVYISNGQVLDSR of } \\
\text { SELK_HUMAN } \\
\text { 1943.9: } \text { MTELETAMGMIIDVFSR of } \\
\text { S100P_HUMAN } \\
\text { Nascent proteins }\end{array}$} \\
\hline 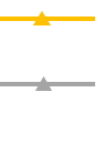 & \multicolumn{4}{|c|}{ 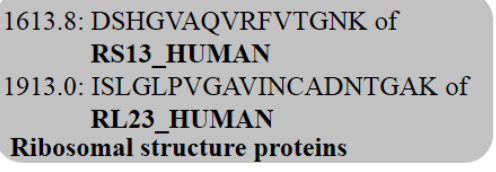 } \\
\hline & 1481.8 & 1943.9 & 1613.8 & 1913.0 \\
\hline Step 1 & $+2488 \%$ & $+54.54 \%$ & $-75.33 \%$ & $-52.03 \%$ \\
\hline Step 2 & $+2816 \%$ & $+72.32 \%$ & $-79.60 \%$ & $-64.97 \%$ \\
\hline Step 3 & $+3332 \%$ & $+133.6 \%$ & $-83.41 \%$ & $-78.67 \%$ \\
\hline
\end{tabular}

Figure S9. Descending acetonitrile gradient washing procedures to avoid non-specific binding. The MS intensities of two characteristic nascent peptides MVYISNGQVLDSR of SELK_HUMAN (blue bars) and

MTELETAMGMIIDVFSR of S100P_HUMAN (orange bars) and two representative non-specific binding peptides DSHGVAQVRFVTGNK of RS13_HUMAN (yellow bars) and ISLGLPVGAVINCADNTGAK of RL23_HUMAN (gray bars) were monitored at each washing off step: non washing (Step 0); washing the reacted PMS with 80\% ACN (Step 1); 60\% ACN (Step 2); 50\% ACN (Step 3). The intensities changes of these peptides were listed in the inset table. 
$\mathbf{A}$

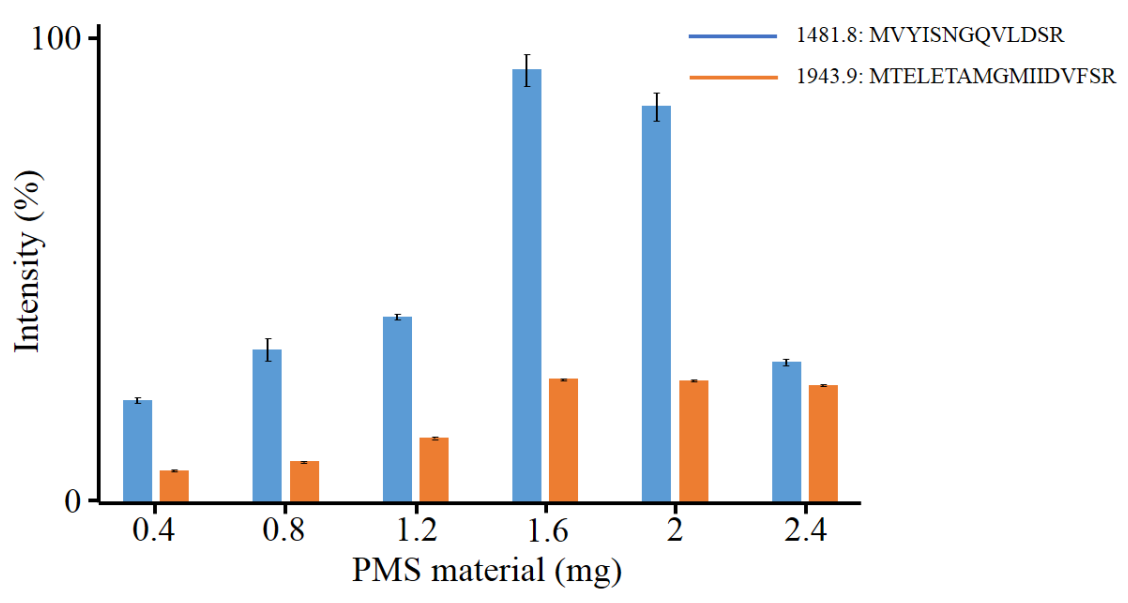

B

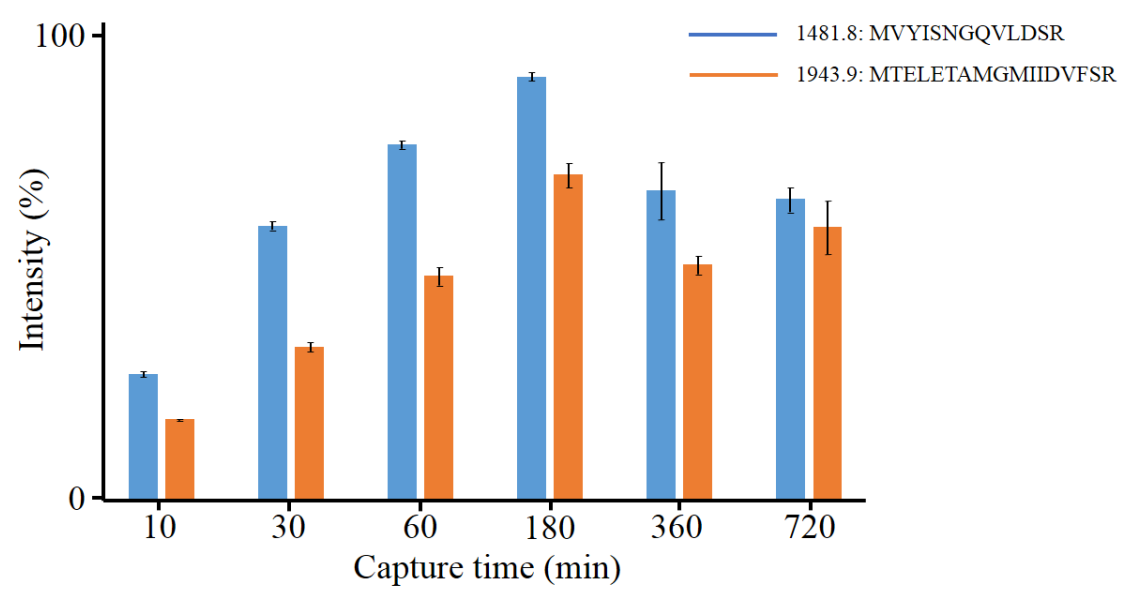

C

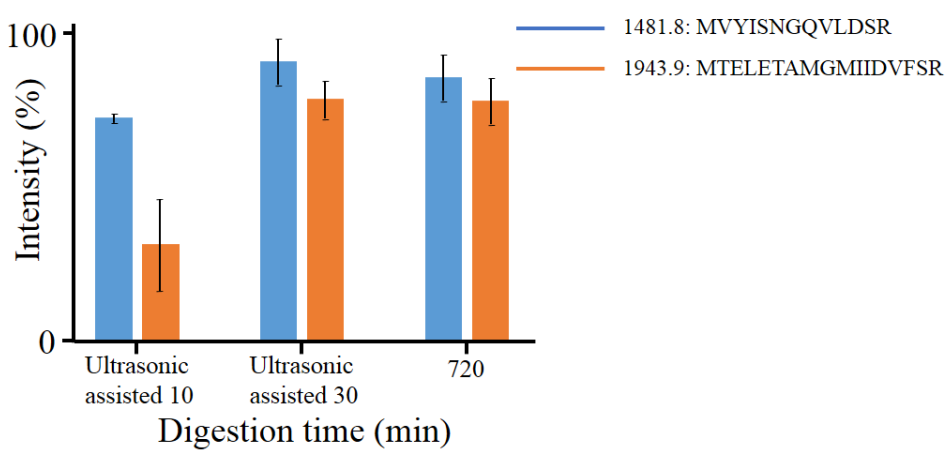

Figure S10. Optimization of the (A) usage amount of PMS, (B) capture time and (C) on beads digestion time for the enrichment of nascent proteins in HeLa RNCs. Characterized nascent peptides MVYISNGQVLDSR (blue bars) and MTELETAMGMIIDVFSR (orange bars) were applied to the quantification of the optimization. 


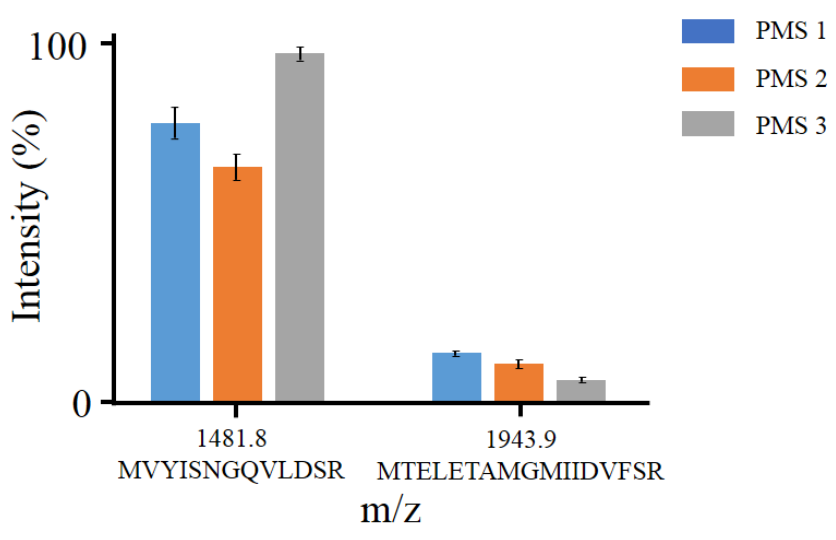

Figure S11. Enrichment reproducibility of PMS evaluated by the triplicate capture of nascent peptides MVYISNGQVLDSR $(\mathrm{m} / \mathrm{z}=1481.8)$ and MTELETAMGMIIDVFSR $(\mathrm{m} / \mathrm{z}=1943.9)$. Blue, orange and gray bars represent enrichment triplicates from three synthetic replicates of PMS. 


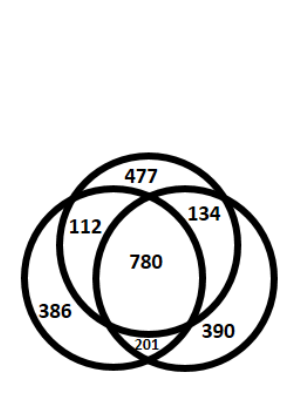

Sum: $\mathbf{2 4 8 0}$

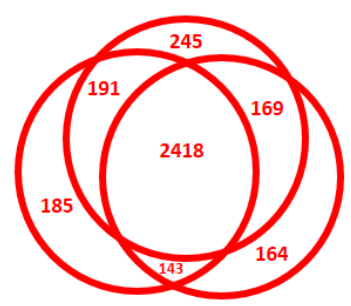

Sum: 3515

Figure S12. Venn diagram of overlapping identified proteins in HeLa RNCs (black circles) and nascent proteins detected by PMSNP (red circles) of the technical triplicates. 
A

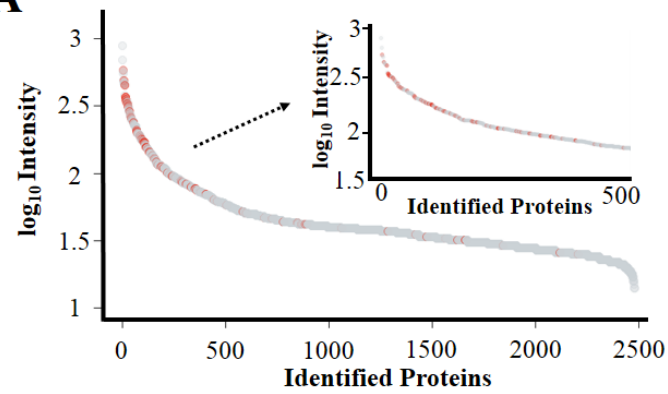

B

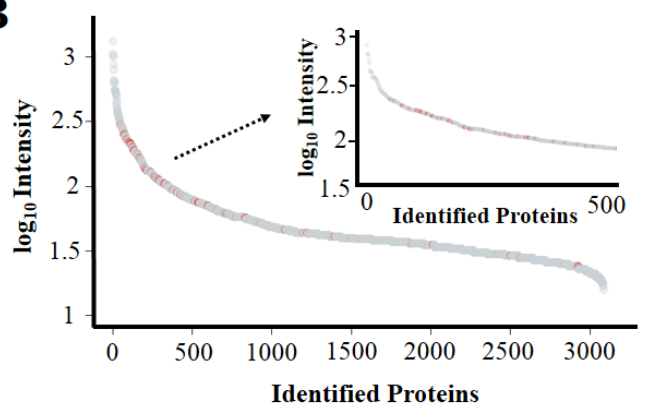

Figure S13. Protein abundance distribution in identified (A) RNCs proteins and (B) nascent proteins in HeLa cells sorted by the protein score. Ribosomal proteins are set as red dots while others are gray dots (Inset: Top 500 proteins abundance distribution). 
A

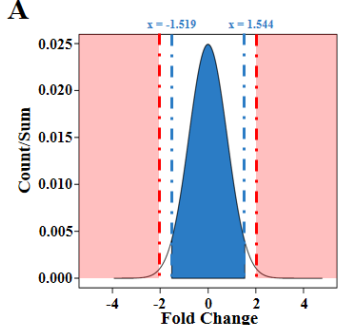

C

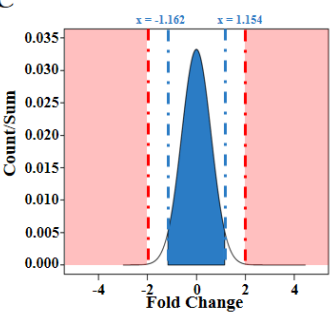

E

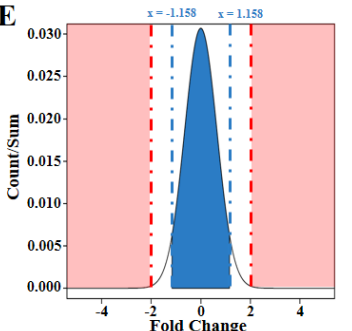

$\mathbf{G}_{0.030}$

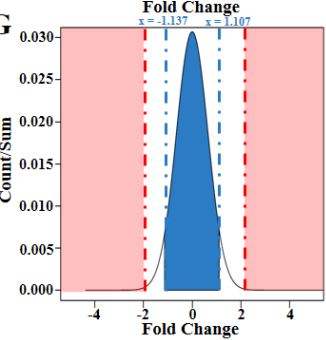

I

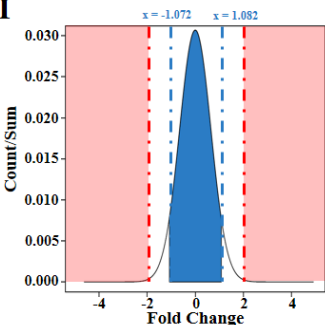

$\mathbf{K}$

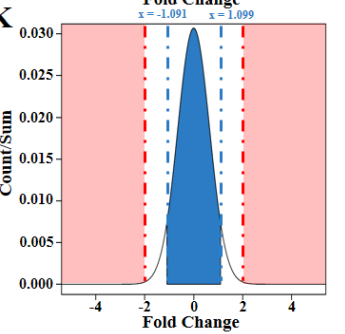

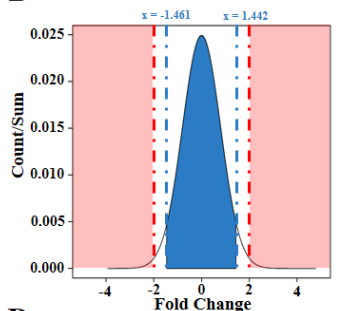

D
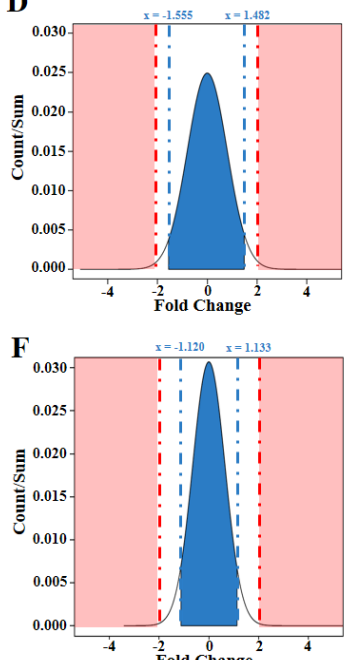

$\mathbf{H}_{0.00}$

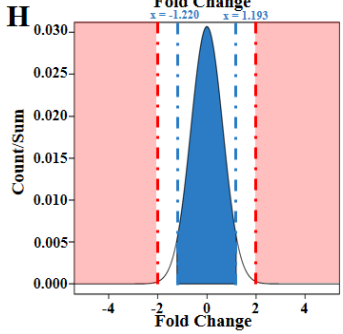

$\mathbf{J}$
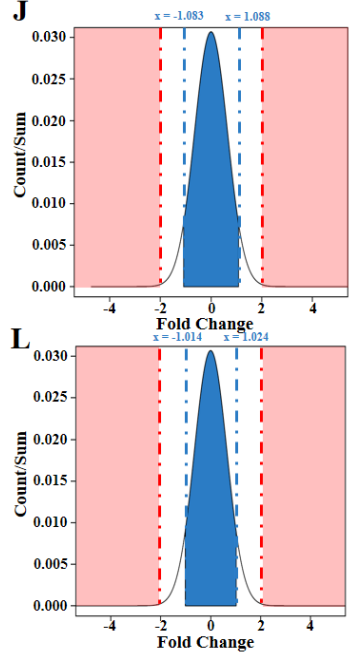

Figure S14. Confidence interval of replicate in each MS identification of (A) HeLa cells RNCs, (B) PMSNP in HeLa cells, (C) Mouse brains proteomes, (D) PMSNP in mouse brains, PMSNP in (E) 0, (F) 10, (G) 30, (H) 60 minute's LPS stimulated HeLa cells, Cellular proteomes in (I) 0, (J) 10, (K) 30, (L) 60 minute's LPS stimulated HeLa cells. The blue dotted lines and blue paint zones marked the limit of confidence interval with the significance level of 0.05 . The red dotted lines and red paint zones indicated the FC $>2$ or $<-2$ as the criteria of filtering significantly differential expressed proteins. 


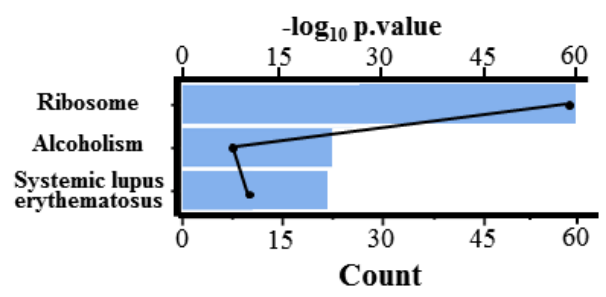

Figure S15. KEGG pathway analysis of identified proteins increased in the expression from HeLa RNCs. 

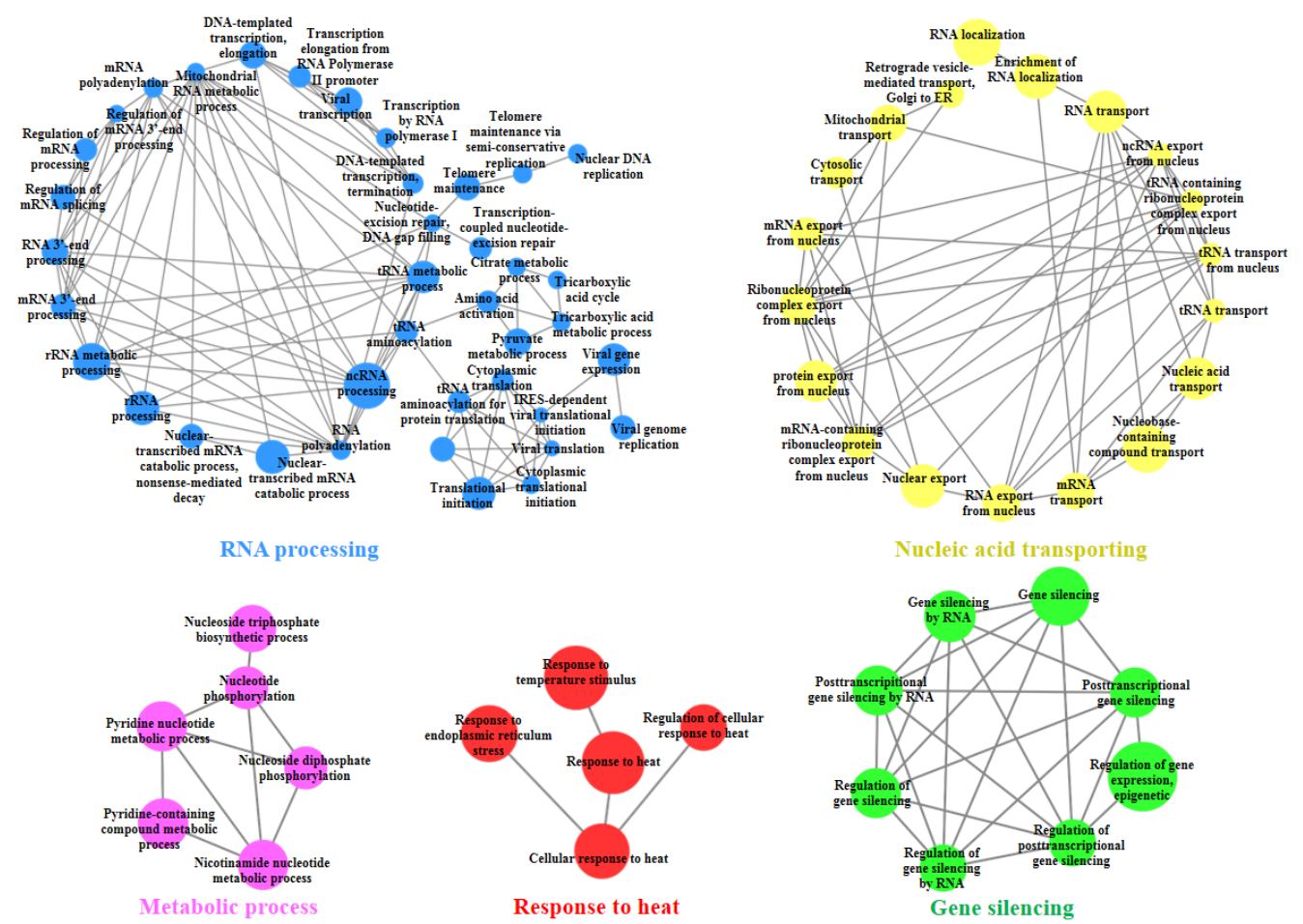

Figure S16. GO terms interaction network of identified nascent proteins in HeLa cells: Different colors represent different biological functions of these interacted terms, which are blue (RNA processing), yellow (nucleic acid transporting), purple (metabolic process), red (response to heat) and green (gene silencing). 


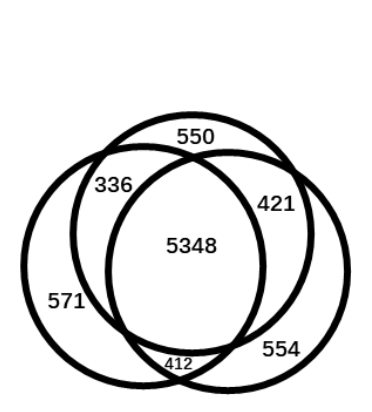

Sum: 8192

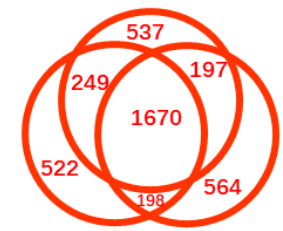

Sum: 3937

Figure S17. Venn diagram of overlapping identified proteins in the full mouse brains (black circles) and nascent proteins from mouse brains detected by PMSNP (red circles) of the technical triplicates. 


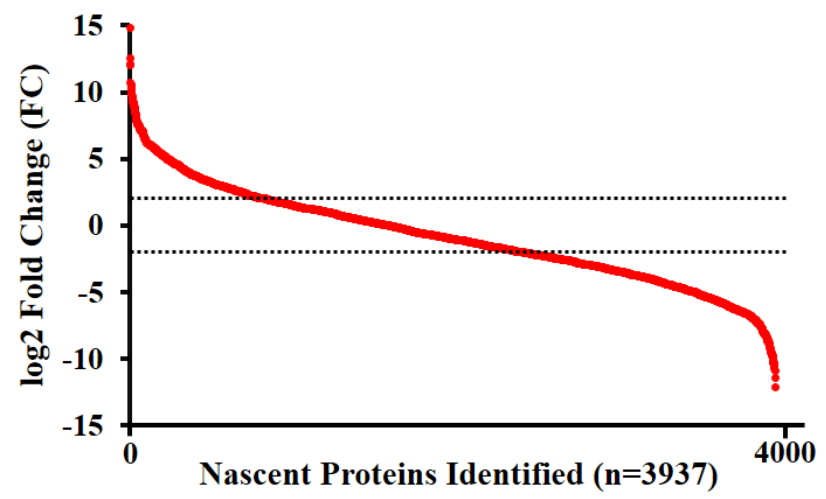

Figure S18. Fold change of 3937 of nascent proteins abundance against full proteins in mouse brains. Dotted line denotes Fold Change $>2$ or $<-2$. 


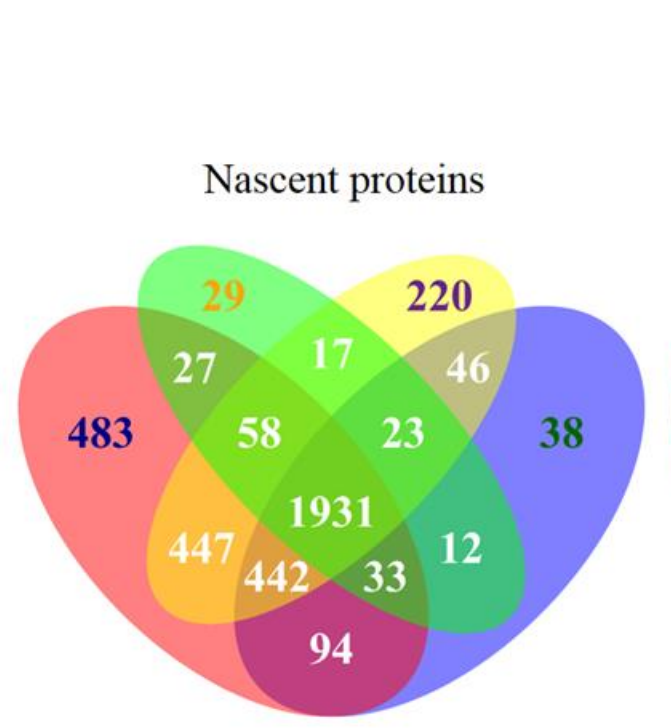

Sum: 4449

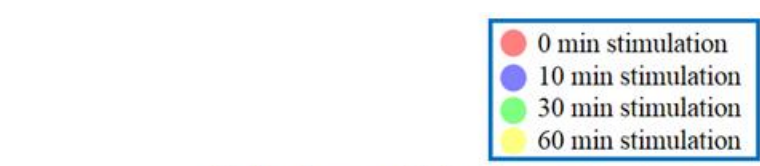

Cellular proteins

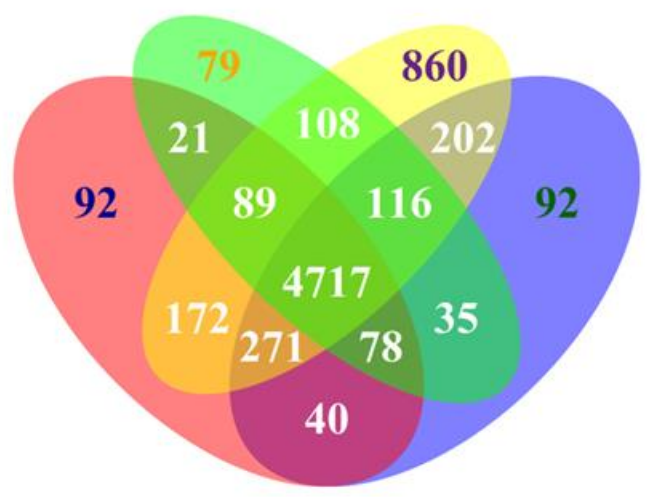

Sum: 6972

Figure S19. Venn diagram of overlapping identified nascent and cellular proteins in the LPS stimulated HeLa cells of four stimulation time groups in technical triplicates. Red circle for 0 minute's stimulation, blue circle for 10 minutes' stimulation, green circle for 30 minutes' stimulation and yellow circle for 60 minutes' stimulation. 


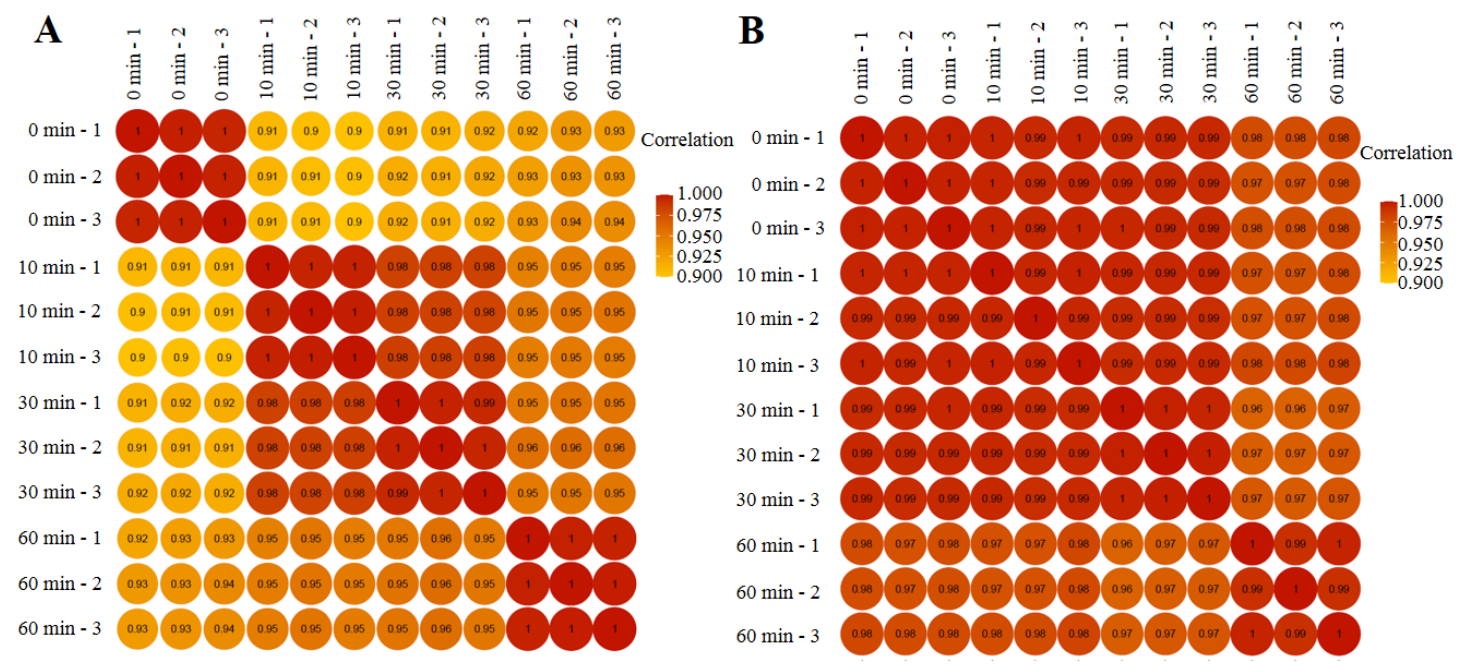

Figure S20. Color-coded Pearson correlation coefficient for the comparison of technical triplicates of identified (A) nascent proteins and (B) cellular proteins in each LPS stimulation time (0, 10, 30 and 60 minutes). The correlation coefficient ranges from 0.9 to 1 . 
Table S1. Comparison of different methods in identification of nascent proteomes.

\begin{tabular}{|c|c|c|c|c|}
\hline Classifications & Methods & $\begin{array}{l}\text { Applicable } \\
\text { Objects }\end{array}$ & $\begin{array}{c}\text { Identified nascent } \\
\text { protein amount }\end{array}$ & Reference \\
\hline \multirow{2}{*}{$\begin{array}{l}\text { Metabolic labeling } \\
\text { methods }\end{array}$} & $\begin{array}{c}\text { Bioorthogonal } \\
\text { noncanonical } \\
\text { amino acid tagging } \\
\text { (BONCAT) }\end{array}$ & Cell culture & $\begin{array}{c}195 \\
(1.95-2.1 \mathrm{mg} \text { of total } \\
\text { protein in HEK293 cell } \\
\text { pellets })\end{array}$ & $\begin{array}{c}\text { Dieterich, D.C. et } \\
\text { al, } 2006^{8}\end{array}$ \\
\hline & $\begin{array}{c}\text { Quantitative } \\
\text { noncanonical } \\
\text { amino acid tagging } \\
\text { (QuaNCAT) }\end{array}$ & Cell culture & $\begin{array}{c}>600 \\
\left(2 \times 10^{6} \text { of primary resting }\right. \\
\mathrm{T} \text { cells })\end{array}$ & $\begin{array}{c}\text { Howden, A.J.M. et } \\
\text { al, } 2013^{9}\end{array}$ \\
\hline \multirow{4}{*}{$\begin{array}{l}\text { Puromycin based } \\
\text { capture methods }\end{array}$} & $\begin{array}{l}\text { Puromycin- } \\
\text { associated nascent } \\
\text { chain proteomics } \\
\text { (PUNCH-P) }\end{array}$ & $\begin{array}{l}\text { Cell culture } \\
\text { Tissue }\end{array}$ & $\begin{array}{c}5000 \\
\left(2.5 \times 10^{7} \text { of HeLa cells }\right) ; \\
4000 \\
(1200 \text { mg of mouse } \\
\text { brains })\end{array}$ & $\begin{array}{l}\text { Aviner, R. et al, } \\
2014^{10}\end{array}$ \\
\hline & $\begin{array}{c}\text { Orthogonal } \\
\text { enzyme-mediated } \\
\text { puromycin } \\
\text { incorporation }\end{array}$ & $\begin{array}{l}\text { Cell culture } \\
\text { Tissue }\end{array}$ & $\begin{array}{c}1165 \\
\left(2 \times 10^{7} \text { of HEK } 293 \mathrm{~T}\right. \\
\text { cells })\end{array}$ & $\begin{array}{c}\text { Barrett, R.M. et al, } \\
2016^{11}\end{array}$ \\
\hline & $\begin{array}{c}\text { OPP mediated } \\
\text { identification } \\
\text { (OPP-ID) of } \\
\text { nascent proteomics }\end{array}$ & $\begin{array}{l}\text { Cell culture } \\
\text { Tissue }\end{array}$ & $\begin{array}{c}1001 \\
\left(2.4 \times 10^{7} \text { of K562 cells }\right) \\
2194 \\
\left(2.4 \times 10^{7} \text { of ESRE cells }\right)\end{array}$ & $\begin{array}{l}\text { Forester, C.M. et } \\
\quad \mathrm{al}, 2018^{12}\end{array}$ \\
\hline & $\begin{array}{c}\text { Puromycin } \\
\text { modified silica } \\
\text { microspheres } \\
\text { assisted nascent } \\
\text { proteomics } \\
\text { (PMSNP) (this } \\
\text { work) }\end{array}$ & $\begin{array}{l}\text { Cell culture } \\
\text { Tissue }\end{array}$ & $\begin{array}{c}3515 \\
\left(1 \times 10^{6} \text { of HeLa cells }\right) ; \\
3937 \\
(33.9 \text { mg of mouse } \\
\text { brains })\end{array}$ & - \\
\hline
\end{tabular}


Table S2. Numbers of proteins identified by PMSNP and cellular proteomics in each LPS stimulation time in HeLa cells.

\begin{tabular}{|c|c|c|}
\hline & Total identified proteins & $\begin{array}{c}\text { Protein identified per MS } \\
\text { run }\end{array}$ \\
\hline $\begin{array}{c}\text { PMSNP in } 0 \text { minute's LPS stimulated } \\
\text { HeLa cells }\end{array}$ & 3515 & $2951 \pm 66$ \\
\hline $\begin{array}{c}\text { Cellular proteomes in } 0 \text { minute's LPS } \\
\text { stimulated HeLa cells }\end{array}$ & 5480 & $4799 \pm 49$ \\
\hline $\begin{array}{c}\text { PMSNP in } 10 \text { minutes' LPS stimulated } \\
\text { HeLa cells }\end{array}$ & 2619 & $2163 \pm 47$ \\
\hline $\begin{array}{c}\text { Cellular proteomes in } 10 \text { minutes' LPS } \\
\text { stimulated HeLa cells }\end{array}$ & 5551 & $4839 \pm 41$ \\
\hline $\begin{array}{c}\text { PMSNP in } 30 \text { minutes' LPS stimulated } \\
\text { HeLa cells }\end{array}$ & 2130 & $1732 \pm 78$ \\
\hline $\begin{array}{c}\text { Cellular proteomes in } 30 \text { minutes' LPS } \\
\text { stimulated HeLa cells }\end{array}$ & 5243 & $4546 \pm 53$ \\
\hline $\begin{array}{c}\text { PMSNP in } 60 \text { minutes' LPS stimulated } \\
\text { HeLa cells }\end{array}$ & 3184 & $2668 \pm 34$ \\
\hline $\begin{array}{c}\text { Cellular proteomes in } 60 \text { minutes' LPS } \\
\text { stimulated HeLa cells }\end{array}$ & 6535 & $5737 \pm 8$ \\
\hline
\end{tabular}


Table S3. Label-free quantified up and down regulated protein amount $(\mathrm{FC}>2$ or $\mathrm{FC}<-2$, and $\mathrm{P}<0.05)$ identified by PMSNP and cellular proteomics in each stimulation time against 0 minute's stimulation. Percentage of the up or down regulated proteins were showed in the brackets.

\begin{tabular}{|c|c|c|c|}
\hline & $10 \mathrm{~min}$ & $30 \mathrm{~min}$ & $60 \mathrm{~min}$ \\
\hline $\begin{array}{c}\text { Up-regulated proteins } \\
\text { identified in cellular } \\
\text { proteomes }\end{array}$ & $85(1.15 \%)$ & $56(0.76 \%)$ & $828(11.2 \%)$ \\
\hline $\begin{array}{c}\text { Down-regulated proteins } \\
\text { identified in cellular } \\
\text { proteomes }\end{array}$ & $49(0.66 \%)$ & $168(2.27 \%)$ & $67(0.91 \%)$ \\
\hline $\begin{array}{c}\text { Up-regulated proteins } \\
\text { identified in nascent } \\
\text { proteomes }\end{array}$ & $44(0.99 \%)$ & $38(0.85 \%)$ & $180(4.05 \%)$ \\
\hline $\begin{array}{c}\text { Down-regulated proteins } \\
\text { identified in nascent } \\
\text { proteomes }\end{array}$ & $795(17.87 \%)$ & $1358(30.52 \%)$ & $427(9.6 \%)$ \\
\hline
\end{tabular}




\section{Reference}

(1) Zhang J.; Wang, X.; Wu, D.; Liu, L; Zhao, H. Bioconjugated Janus Particles Prepared by in Situ Click Chemistry. Chem. Mater. 2009, 21, 4012-4018.

(2) Ortega-Muñoz, M.; Lopez-Jaramillo, J.; Hernandez-Mateo, F.; Santoyo-Gonzalez, F. Synthesis of Glyco-Silicas by $\mathrm{Cu}(\mathrm{I})$-Catalyzed "Click-Chemistry" and their Applications in Affinity Chromatography. Adv. Synth. Catal. 2006, 348, 2410-2420.

(3) Cox, J.; Mann, M. MaxQuant Enables High Peptide Identification Rates, Individualized p.p.b.-range Mass Accuracies and Proteome-wide Protein Quantification. Nat. Biotechnol. 2008, 26, 1367-1372.

(4) Tyanova, S.; Temu, T.; Carlson, A.; Sinitcyn, P.; Mann, M.; Cox, J. Visualization of LC-MS/MS Proteomics Data in MaxQuant. Proteomics 2015, 15, 1453-1456.

(5) Tyanova, S.; Temu, T.; Sinitcyn, P.; Carlson, A.; Hein, M. Y.; Geiger, T.; Mann, M.; Cox, J. The Perseus Computational Platform for Comprehensive Analysis of (prote)omics Data. Nat. Methods 2016, 13, 731-740.

(6) Doll, S.; Urisman, A.; Oses-Prieto, J.A.; Arnott, D.; Burlingame, A.L. Quantitative Proteomics Reveals Fundamental Regulatory Differences in Oncogenic HRAS and Isocitrate Dehydrogenase (IDH1) Driven Astrocytoma. Mol. Cell. Proteomics 2017, 16, 39-56.

(7) Chen, J.; Liu, M.; Chen, C.; Gong, H.; Gao, C. Synthesis and Characterization of Silica Nanoparticles with Well-Defined Thermoresponsive PNIPAM via a Combination of RAFT and Click Chemistry. ACS Appl. Mater. Interfaces, 2011, 3, 3215-3223.

(8) Dieterich, D.C.; Link, A.J.; Graumann J.; Tirrell, D.A.; Schuman, E.M. Selective identification of newly synthesized proteins in mammalian cells using bioorthogonal noncanonical amino acid tagging (BONCAT). Proc. Natl. Acad. Sci. U.S.A., 2006, 103, 9482-9487.

(9) Howden, A.J.M.; Geoghegan, V.; Katsch, K.; Efstathiou, G.; Bhushan, B.; Boutureira, O.; Thomas, B.; Trudgian, D.C.; Kessler, B.M.; Dieterich, D.C.; Davis, B.G.; Acuto, O. QuaNCAT: quantitating proteome dynamics in primary cells. Nat. Methods, 2013, 10, 343-346.

(10)Aviner, R.; Geiger, T.; Elroy-Stein, O. Genome-wide Identification and Quantification of Protein Synthesis in Cultured Cells and Whole Tissues by Puromycin-associated Nascent Chain Proteomics (PUNCH-P). Nat. Protoc., 2014, 9, 751-760.

(11)Barrett, R.M.; Liu, H.; Jin, H.; Goodman, R.H.; Cohen, M.S. Cell-specific Profiling of Nascent Proteomes Using Orthogonal Enzyme-mediated Puromycin Incorporation. ACS Chem. Biol., 2016, 11, 1532-1536.

(12)Forester, C.M.; Zhao Q.; Phillips, N.J.; Urisman, A.; Chalkley, R.J.; Oses-Prieto, J.A.; Zhang L.; Ruggero, D.; Burlingame, A.L. Revealing Nascent Proteomics in Signaling Pathways and Cell Differentiation. Proc. Natl. Acad. Sci. U.S.A., 2018, 115, 23532358. 